\title{
Sickle Cell Disease among Blacks; the Possible Pivotal Role of Precision Medicine: A Focused Review on Management of Pain
}

\author{
${ }^{* 1}$ M. A., Ndakotsu and 2S.A. Balarabe \\ 1Department of Heamatology and blood transfusion, Usmanu Danfodiyo University Teaching Hospital Sokoto, Nigeria \\ 2Department of Medicine, Usmanu Danfodiyo University Teaching Hospital Sokoto, Nigeria \\ [Corresponding Author: E-mail: mndakotsu@yahoo.com; D+234 8035073579]
}

\section{ABSTRACT}

Sickle Cell Disease (SCD) occurs commonly in sub- Saharan African region. For instance, out of the estimated 305,800 babies born annually with SCD worldwide about $75 \%$ occurred in sub-Saharan Africa (SSA). Vasoocclusive painful crisis is the prototype clinical event among SCD patients with nearly all SCD persons experiencing the episode during their lifetime. Additionally, acute vasooculusive pain crises may eventually progressed to chronic pain, resulting in poor quality of life associated with other morbidities, including anxiety, depression and dependence on pain medications. Transformation and technological development that brought about new clinical approaches and treatments have increased rates of survival in patients with Sickle Cell Disease (SCD). However, the overall life expectancy of such patients remains shorter than other normal populations. Therefore, management of pain should be guided by an individualized précised prescribing and monitoring protocol. To this end, the concept of precision medicine that is predicated on using practical application of human genomics provide an evolving set of translational research goals in the management of pain in sickle cell disease. This review tend to shed light on this new concept, hoping that the review will facilitate improved and more accessible care for all patients leaving with sickle cell disease.

Keywords: Sickle cell disease, Precision medicine, Pain management, Sickle cell crisis, Hydroxyurea.

\section{INTRODUCTION}

Sickle cell disease (SCD) was first reported by Herrick in 1910 (Herrick JB. 1910). Since then substantial knowledge about SCD has been acquired. It is a single amino acid inherited disorder of a nucleotide mutation, resulting from amino acid substitution from glutamic acid to valine at position 6 on the $\beta$-globin subunit. This mutation causes hemoglobin $S(\mathrm{HbS})$ to polymerizes, resulting in sickling of erythrocyte that becomes more rigid, with the consequent expression of various cellular adhesion molecules (Bunn, 1997; Ballas and Mohandas, 2004).

Sickle cell disease is one of the most common inherited blood disorders affecting millions of people globally in humans and is associated with myriad complications in Humans (Piel et al., 2017, Kato et al., 2018). Sickle cell disease is a single amino acid substitution in the $\beta$-globin chain that lead to formation of mutant hemoglobin $\mathrm{S}(\mathrm{HbS})$ which can polymerize in red cells under certain conditions, resulting in a complex cascade of processes that include but not limited to erythrocyte sickling, intravascular hemolysis, increased adhesion of red cells to the endothelium of blood vessels, activation of platelets, production of inflammatory cytokines, and subsequently result in vascular occlusion (Ware et al., 2017). Repeated hemolysis and anemia result in vascular damage and tissue hypoxia, which may lead to multiorgan damage and an increased risk of death (DeBaun et al., 2012; Nath and Hebbel, 2015; Gladwin, 2016; Kato et al., 2017). Early detection, ideally by means of screening and institution of preventive measures may save lives. For almost two decades now, only two medications approved by the Food and Drug Administration are available (hydroxyurea and I-glutamine [USAN, glutamine]) (Niihara et al., 2018).

Although research findings reported beneficial effect of hydroxyurea (Nevitt et al., 2017), in 
reducing frequencies of hospital admissions for painful crisis among sickle cell diseases patients, use of the agent remains low especially in resource limited societies and chronic medical complications and early death in persons with sickle cell disease remain a substantial burden. In particular, chronic organ dysfunction has become a leading cause of death in adults with sickle cell disease in the United States (Lanzkron et al. 2013; Vichinsky, 2017). Additionally, hematopoietic stem cell transplantation, the only possible curative therapy, has been used in only developed, economically advantage nations, covering a small fragment of affected patients.

\section{Clinico-Pathological Features of Sickle Cell Disease}

Vasoocclusive painful crisis is the prototype of acute complications of sickle cell disease, with nearly all SCD persons experiencing a vasoocclusive crisis during their lifetime. The initial crisis usually occur during childhood, often presenting as dactylitis, and subsequently with variable frequency, affecting the extremities, chest, and back (Ballas and Lusardi, 2005; Jacob, 2005; Smith et al., 2008). Therefore, attending physicians should clearly understand and appreciate the severe nature of the pain and the urgent need for effective therapies. Sickle cell disease patients presenting with a vasoocclusive crisis are at high risk of other well defined acute complications such as acute chest syndrome (ACS), which can rapidly progressed to respiratory failure and requires immediate evaluation and effective management with antibiotics, oxygen and blood transfusion.

The painful crisis may result from avascular necrosis of bone marrow and the source of the pain is presumed to be an increased intramedullary pressure consequent on the ensuing inflammatory process. The pathological evidence implicating bone marrow necrosis in painful crisis include: (a) presence of necrotic marrow on aspiration from sites of pains (b) Bone scintigraphic evidence of increased calcium turnover (c) Magnetic Resonance Imaging (MRI) evidence of acute infarction and edema (d) Confinement of pain to the site of active bone marrow with occasional evidence of myonecrosis and myofibrosis (Graham and Bonyl, 2001). Other less common complications include acute cholecystitis, hepatobiliary complications, acute splenic sequestration, priapism, acute kidney injury, acute aplastic crisis infection and stroke. These other acute complications of SCD require effective management that is better guided by pharmacogenetics.

Some of the above mentioned acute complications of SCD such as stroke, may not resolve completely but rather, evolve into subacute or chronic phases that require special attention and approaches to management (Diatchenko et al., 2005). For instance, sickle cell acute pain crises may eventually progressed to chronic pain, resulting in poor quality of life (Embury, 1994; Bellet et al., 1995; Dampier, 2002; Ballas et al., 2010), associated with other morbidities, including loneliness, anxiety, depression, despair, insomnia, and dependence on pain medications (Benjamin et al., 1999; Serjeant and Serjeant, 2001; Adams and Brambilla, 2005). On the other hand chronic complications of SCD can evolve gradually during the lifespan of affected persons.

Chronic complications such as avascular necrosis, occurs in about one out of ten sickle cell disease patients, and the hip joint is the most common area affected (Milner et al., 1991). This complication often causes chronic severe pain and disability. Therapy is usually conservative, although, surgical approach in form of joint replacement may be necessary.

Pulmonary Arterial Hypertension due to restriction and stiffness of the walls of pulmonary artery may resulting in elevation of mean pulmonary arterial pressure (>25 $\mathrm{mm} \mathrm{Hg}$ at rest). This complication is an independent risk factor for mortality in SCD (Parent et al., 2011). 
Chronic kidney disease, may be seen in about $4 \%$ to $18 \%$ of persons with SCD (Ataga and Orringer, 2000). In a study in US, renal failure was reported in $4.2 \%$ of persons with SCA. Additionally, among those developing renal failure, $68 \%$ previously had proteinuria, $40 \%$ had nephrotic syndrome, and $33 \%$ had hypertension (Powars et al., 1991).

Chronic leg ulcers are other form of long-term vascular complication seen among sickle cell disease patients and are treated with standard therapy as well as evaluation for venous etiologies. Antibiotic therapy is reserved for ulcers with culture-proven bacterial infection. When ulcers are persistent, coexistence of osteomyelitis should be assessed.

\section{Management of pain in Sickle Cell Disease}

It is particularly important that, pain management should include strategies employed to control attack in a timely manner, guided by an individualized prescribing and monitoring protocol (Bellet et al., 1995). Transformation and technological development that brought about, new clinical approaches and treatments have increased rates of survival in patients with $S C D$ (Gaston et al., 1986; Adams. et al 1989; Adams and Brambilla. 2005). However, the overall life expectancy of such patients remains shorter than other normal populations, largely accounted for by both acute and chronic complications of SCD (Kochanek et al., 2011; Sheth et al., 2013).

As far back as about four decade ago, hydroxyurea was identified as a promising drug candidate for SCD by increasing fetal hemoglobin levels. Since then oral daily dose hydroxyurea therapy has been shown to reduce many acute and chronic complications of SCD (Paule et al., 2011). Additional mechanisms through which hydroxyurea mitigate acute and long-term complications of sickle cell disease include: reducing the quantity of circulating red blood and white blood cells, decreasing cellular expression of adhesion molecules, (thereby reducing vasooculusion) (Ware, 2010). Hydroxyurea also increases mean corpuscular volume of reticulocytes and by extension improves cellular deformability, which in turn increases blood flow and reduces vasoocclusion. Furthermore, nitric oxide released by hydroxyurea metabolism may lead to vasodilation (King, 2004). Therefore, oral daily hydroxyurea treatment substantially reduces the number and severity of painful episodes (Charache et al., 1995). More importantly, Longterm hydroxyurea therapy may results in a reduction in mortality (Steinberg et al., 2003; Voskaridou et al., 2010).

Possible Role of Precision Medicine in Managing Vasooculusive Pain Crisis

Precision medicine as a continuous fundamental process that aims to improve the effectiveness and efficiency of clinical practice, through better understanding of how the unique biological characteristics of patients and their social or environmental factors influences their health and disease, holds strong potentials to transform quality of pain management and improve patient outcomes among individuals with sickle cell disease. The drivable benefits for patients and the healthcare delivery system include: more precise diagnosis and prognosis, well targeted and personalized interventions, as well as good understanding and prediction of individual disease risk. All these could summon to more efficient and effective use of healthcare delivery system resources, especially in resource limited societies, such as Sub-Saharan Africa. Furthermore, Precision medicine provide a unique opportunity to move away from a one size fits all approach to the management and care of patients with pain crises, to one which uses new approaches that better manage patients' background condition and target therapies to achieve the best outcomes in the management of a patient's disease or predisposition to disease.

\section{Use of Opioids Analgesics}

One of the most interesting developments in basic science related to practical application of precision medicine is the progress so far made in understanding the pharmacodynamics and 
pharmacokinetics of opioids. Foremost among these was the mechanism of action of opioids in relieving pain. In the 1970s, it was hypothesized that opioids have receptors to bind and activate in order to relieve pain by blocking or minimizing the transmission of painful stimuli and raising the pain threshold (Voskaridou et al., 2010). It did not take long after that to identify opioids as ligands that bind to saturable receptors in the central nervous system (Beckett and Casy.1954; Pert and Snyder,1973). It was reported that, the binding affinity of opioids to its receptors varies considerably and that, the binding affinities of opioids correlate with their analgesic potencies (Kosterlitz,1975; Snyder,1984). At the molecular level it was found that, opioids initiate chain reactions that include but not limited to: activation of $\mathrm{G}$ proteins, inhibition of adenylate cyclase, and extrusion of potassium ions, leading to hyperpolarization, which in turns delays transmission of painful stimuli (Herz, 1971; Martin,1976; Snyder,1977; Simon and Hiller,1978; Ballas, 2015).

Additionally, advancement in understanding the pharmacokinetics of opioids metabolism revealed the role of CYP enzymes and uridine diphosphate glucuronyltransferase (UGT) enzymes in Glucuronidation of opioids, as well as the cytochrome P450 isoenzyme system. The net effect of opioid analgesics depends on the availability of these enzyme(s) to convert it into metabolites. For instance, the CYP2D6 genotypes are categorized into phenotypes with Ultrarapid metabolizers (UMs) having greater than normal activity due to duplication or triplication, of active alleles, extensive metabolizers (EMs) have normal enzyme activity, while intermediate metabolizers (IMs) have decreased enzyme activity, and poor metabolizers (PMs) have absent or little enzyme activity (Sery et al., 2005; Shord et al., 2009; Neafsey, 2009; McGregor et al. 2012). Therefore, Patients who are UMs of some opioids like fentanyl would rapidly convert it into inactive metabolites with minimal or absent analgesic effect requiring increasing the dose of fentanyl.
On the other hand, patients who are PMs of fentanyl would experience prompt relief with relatively small doses of fentanyl but higher doses could be toxic due to the accumulation of unmetabolized fentanyl (Lotsch et al., 2004). With these observations, it is obvious that, technological development and better understanding of pharmacodynamics and pharmacokinetics of opioids demonstrate variability of genotypes among sickle cell disease patients and even more variability in individual responses to opioids. Therefore, evaluating the pharmacogenetics profile of each patient facilitates the rational drug choice that would be efficacious for that patient. This approach in diagnostics and therapeutics brought to the fore the dawn of a new trend in the management of pain among sickle disease patients based on their unique biomarker characteristics, phenotypic and pharmacogenetics. This laudable approach is referred to as precision medicine (Jameson and Longo, 2015).

\section{Application of Pharmacogenomics:}

Indeed, Environmental and genetic factors influence many pathophysiological mechanisms of SCD that contribute to a highly variable clinical expression in individual patients. Pain in SCD is classified as acute, chronic, and mixed pain, which varies in severity (Ballas et al., 2012; 2015; Steinberg et al., 2010). Genetic differences appeared to be the major factor for interindividual variability in pain perception and variable responses to anti-inflammatory and opioid drugs (Chou et al., 2006). People who are homozygous for $118 \mathrm{~A}>\mathrm{G}$ polymorphism in the OPRM1 (a major site of action for most opioid analgesics) have more pain and need more morphine for management of their pain (Klepstad et al., 2004). On the other hand Single-nucleotide polymorphisms (SNPs) in the COMT gene affects pain sensitivity and low COMT activity may lead to increased levels of catecholamine, which results in more pain sensitivity (Slade et al., 2007). 


\section{Pharmacogenomics of Pain Susceptibility in SCD:}

The initial pain in vasooculusive crisis serve as an alert mechanism in response to tissue injury which may worsen and persist to a chronic pain (Ballas and Lusardi, 2005; Todd et al., 2006). Chronic Pain in SCD has a direct impact on the quality of life of patients (Kanter and KruseJarres, 2013). The pain may be associated with psychopathology disturbances such as anxiety, depression and personality disorder (Dersh et al., 2002). Several studies on pain perception and response to opioids, found that genomic variations influence both perception and vulnerability to chronic pain (Stamer and Stuber, 2007). Furthermore, SNPs of specific genes were associated with variable degrees of pain perception, leading to the hypothesis that some variants were located in genes related to the inflammatory process of vasoocclusive painful crises, resulting in nerve and tissue damage and thus the development of secondary pain (Mogil, 2004; Diatchenko et al., 2005).

It is reported that a polymorphism in the GTP cyclohydrolase (GCH1) on chromosome 14 (rs8007267) among African-Americans, is associated with pain crises (Belfer et al., 2014).This enzyme catalyzes the rate-limiting step for tetrahydrobiopterin synthesis, thus variation in its gene is likely to have pathophysiological roles in pain. Additionally, polymorphism of single nucleotide (rs614803) located in a region about $8 \mathrm{~kb}$ from the COMM domain-containing protein COMMD7 is significantly associated with painful crises; COMMD7 is a modulator of many proteins and is associated with NF-kappa-B complex. Similarly, genetic studies among Egyptians reported the GSTM1 null allele to be significantly associated with increased risk of severe vaso-occlusive crises (Shiba, 2014). GSTM1 catalyzes the addition of glutathione on molecules to increase the antioxidant status. Furthermore, there reported cases of higher incidence of pain observed among SCD patients who were carriers of the methylenetetrahydrofolate reductase
(MTHFR; C677T) polymorphism as well as Factor V Leiden (FVL; G191A) polymorphism (Nishank et al., 2013).

\section{CONCLUSION}

Management of pain among patients with Sickle cell disease can be quiet challenging to both the patient and attending clinician. However, the growing personalization of medicine predicated on the concept of precision medicine, has brought about fundamental changes aimed at improving the effectiveness and efficiency of clinical practice by better understanding how the unique biological characteristics of individuals and their social and/or environmental contexts contribute to their health and disease. For instance, in the last century, sickle cell pain was treated by guess work through dose escalation or reduction of dose of opioids or substitution of one analgesic for the other. Now, better understanding of opioid receptors structure and the role of the CYP450 enzymes in metabolizing opioids has revealed that these anatomic and metabolic entities are not the same in all persons, which explains the variability in response to opioids among sickle cell disease patients.

\section{REFERENCES}

Adams RJ and Brambilla D. (2005). Optimizing Primary Stroke Prevention in Sickle Cell Anemia (STOP 2) Trial Investigators. Discontinuing prophylactic transfusions used to prevent stroke in sickle cell disease. New England Journal of Medicine, 353(26):2769-2778.

Adams RJ, McKie VC, Hsu L, Files B, Vichinsky E, Pegelow C, Abboud M, Gallagher D, Kutlar A, Nichols FT, Bonds DR, Brambilla D. (1998). Prevention of a first stroke by transfusions in children with sickle cell anemia and abnormal results on transcranial Doppler ultrasonography. New England Journal Medicine, 339 (1):5-11.

Ataga KI, Orringer EP. (2000). Renal abnormalities in sickle cell disease. 
Ndakotsu and Balarabe: Sickle Cell Disease among Blacks; the Possible Pivotal Role of Precision...

American Journal of Hematology, 63(4):205-211.

Ballas SK. (2015). Pathophysiology and principles of management of the many faces of the acute vaso-occlusive crisis in patients with sickle cell disease. European Journal Haematology, 95(2):113-123.

Ballas SK, Gupta K, and Adams-Graves P. (2012). . Sickle cell pain: A critical reappraisal. Blood, 120:(18) 3647-3656.

Ballas SK, Lieff S, Benjamin LJ, Dampier CD, Heeney MM, Hoppe C, Johnson CS, Rogers ZR, Smith-Whitley K, Wang WC, Telen MJ., (2010). Investigators, Comprehensive Sickle Cell Centers. Definitions of the phenotypic manifestations of sickle cell disease. American Journal Hematology, 85(1):613.

Ballas SK, Lusardi M. (2005). Hospital readmission for adult acute sickle cell painful episodes: frequency, etiology, and prognostic significance. American Journal Hematology, 79(1):17-25

Ballas SK, Mohandas N. (2004). Sickle red cell microrheology and sickle blood rheology. Microcirculation, 11(2):209-225.

Beckett AH, Casy AF. (1954). Synthetic analgesics: stereochemical considerations. Journal of Pharmacy and Pharmacology, 6(12):986-1001.

Belfer I, Youngblood V, Darbari DS, Wang Z, Diaw L, Freeman L, et al. (2014). A GCH1 haplotype confers sex-specific susceptibility to pain crises and altered endothelial function in adults with sickle cell anemia. American Journal Hematology, 89(2):187-193.

Bellet PS, Kalinyak KA, Shukla R, Gelfand MJ, Rucknagel DL. (1995). Incentive spirometry to prevent acute pulmonary complications in sickle cell diseases. New England Journal Medicine, 333(11):699-703.

Benjamin LJ., Dampier CD., Jacox AK., Odesina V., Phoenix D., Shapiro B., Strafford M.,
Treadwell M. (1999). Guideline for the Management of Acute and Chronic Pain in Sickle-Cell Disease. Chicago, IL: American Pain Society.

Bunn HF. (1997). Pathogenesis and treatment of sickle cell disease. New England Journal Medicine, 337(11):762-769.

Charache S, Terrin ML, Moore RD, Dover GJ, Barton FB, Eckert SV, McMahon RP, Bonds DR. (1995). Investigators of the Multicenter Study of Hydroxyurea in Sickle Cell Anemia. Effect of hydroxyurea on the frequency of painful crises in sickle cell anemia. New England Journal Medicine, 332(20):1317-1322.

Chou W, Wang C, Liu P, Liu C, Tseng C, and Jawan, B. (2006) . Human opioid receptor A118G polymorphism affects intravenous patient-controlled analgesia morphine consumption after total abdominal hysterectomy. Anesthesiology, 105(2):334-337.

Dampier C, Ely B, Brodecki D, O'Neal P. (2002). Characteristics of pain managed at home in children and adolescents with sickle cell disease by using diary self-reports. Journal of Pain, 3(6):461-470.

DeBaun MR, Armstrong FD, McKinstry RC, Ware RE, Vichinsky E, Kirkham FJ.(2012). Silent cerebral infarcts: a review on a prevalent and progressive cause of neurologic injury in sickle cell anemia. Blood, 119: 4587-96.

Dersh J, Polatin PB, and Gatchel RJ. (2002). Chronic pain and psychopathology: Research findings and theoretical considerations. Psychosomatic Medicine, 64(5):773-786.

Diatchenko L, Slade GD, Nackley AG, Bhalang K, Sigurdsson A, Belfer I, Goldman D, Xu K, Shabalina SA, Shagin D, Max MB, Makarov SS, Maixner W. (2005). Genetic basis for individual variations in pain perception and the development of a chronic pain condition. Human Molecular Genetics, 14(1):135-143. 
Embury SH, Hebbel RP, Mohandas S, eds. Sickle Cell Disease: Basic Principles and Clinical Picture. New York, NY: Raven Press; 1994.

Farrell K, Dent L, Nguyen ML, Buchowski M, Bhatt A, Aguinaga MdelP. (2010). The relationship of oxygen transport and cardiac index for the prevention of sickle cell crises. Journal of the National Medical Association, 102(11):1000-1007.

Gaston MH., Verter Jl., Woods G., Pegelow C., Kelleher J., Presbury G., Zarkowsky H., Vichinsky E., lyer R., Lobel JS., Diamond S., C. Tate Holbrook CT (1986). Prophylaxis with oral penicillin in children with sickle cell anemia: a randomized trial. New England Journal Medine, 314(25):1593-1599.

Gladwin MT. (2016). Cardiovascular complications and risk of death in sicklecell disease. Lancet, 387: 2565-74.

Graham R. Sergent and Bery E. Sergent (2001). Sickle Cell Disease, Third ed. Oxford University Press Inc., New York, Pp 281

Herrick JB. (1910). Peculiar elongated and sickleshaped red blood corpuscles in a case of severe anemia. The Archives of Internal Medicine, 6(5):517-521.

Herz A, Teschemacher HJ. (1971). Activities and sites of antinociceptive action of morphine-like analgesics and kinetics of distribution following intravenous intracerebral and intraventricular application. Advances in Drug Research, 6:79.

Hsieh MM, Kang EM, Fitzhugh CD, Link MB, Bolan CD, Kurlander R, Childs RW, Rodgers GP, Powell JD, Tisdale JF. (2009). Allogeneic hematopoietic stemcell transplantation for sickle cell disease. New England Journal Medicine, 361(24):2309-2317.

Jacob E, Beyer JE, Miaskowski C, SavedraM, TreadwellM, Styles L. (2005). Are there phases to the vaso-occlusive painful episode in sickle cell disease? Journal of
Pain Symptom Management, 29(4):392400.

Jameson JL, Longo DL. (2015). Precision medicine - personalized, problematic, and promising. New England Journal Medicine, 372(23):2229-2234.

Kanter J, and Kruse-Jarres R.(2013). Management of sickle cell disease from childhood through adulthood. Blood Reviews, 27(6):279-287.

Kato GJ, Steinberg MH, Gladwin MT. (2017). Intravascular hemolysis and the pathophysiology of sickle cell disease. Journal of Clinical Investigation, 127: 750-60.

Kato GJ, Piel FB, Reid CD, Gaston MH, OheneFrempong K, Krishnamurti L, Smith WR, Panepinto JA, Weatherall DJ, Costa FF, Vichinsky EP ( 2018). Sickle cell disease. Nature Reviews Disease Primer, 15(4):18010. doi: 10.1038/nrdp.2018.10

King SB. Nitric oxide production from hydroxyurea.(2004). Free Radical Biology and Medicine, 37(6):737-744.

Klepstad P, Rakva ${ }^{\circ} \mathrm{g}$ T, Kaasa S, Holthe M, Dale 0 , Borchgrevink PC, et al. (2004). The $118 \mathrm{~A}>\mathrm{G}$ polymorphism in the human Iopioid receptor gene may increase morphine requirements in patients with pain caused by malignant disease. Acta Anaesthesiologica Scandinavica, 48(10):1232-1239.

Kochanek KD, Xu J, Murphy SL, Minino AM, Kung HC. Deaths. (2011): preliminary data for 2009. National Vital Statistics Reports, 59(4):1-51.

Kosterlitz WH. (1975). Opiate actions in guinea pig ileum and mouse vas deferens. Neurosciences Research Bulletin, 13:6870.

Lanzkron S1, Strouse JJ, Wilson R, Beach MC, Haywood C, Park H, Witkop C, Bass EB, Segal JB (2008). Systematic review: hydroxyurea for the treatment of adults with sickle cell disease. Annals of Internal Medicine, 148(12):939-955. 
Ndakotsu and Balarabe: Sickle Cell Disease among Blacks; the Possible Pivotal Role of Precision...

Lanzkron S, Carroll CP, Haywood C Jr.( 2013). Mortality rates and age at death from sickle cell disease: U.S., 1979-2005. Public Health Reports, 128: 110-6

Lotsch J, Skarke C, Liefhold J, Geisslinger G. (2004). Genetic predictors of the clinical response to opioid analgesics: clinical utility and future perspectives. Clinical Pharmacokinetics, 43(14):983-1013.

Martin WR, Eades CG, Thompson JA, Huppler RE, Gilbert PE. (1976). The effects of morphine- and nalorphine- like drugs in the nondependent and morphinedependent chronic spinal dog. The Journal of Pharmacology Experimental Therapeutics, 197(3):517-532.

McGregor LM, Stewart CF, Crews KR, Tagen M, Wozniak A, Wu J, McCarville MB, Navid F, Santana VM, Houghton PJ, Furman WL, Rodriguez-Galindo C. (2012). Dose escalation of intravenous irinotecan using oral cefpodoxime: a phase I study in pediatric patients with refractory solid tumors. Pediatric Blood and Cancer, 58(3):372-379.

Milner PF, Kraus AP, Sebes JI, Sleeper LA, Dukes KA, Embury SH, et al. (1991). Sickle cell disease as a cause of osteonecrosis of the femoral head. New England Journal Medicine, 325(21):14761481.

Mogil JS. (2004). Complex trait genetics of pain in the laboratory mouse. Pain Research and Management, 28:123-150.

Nath KA, Hebbel RP.(2015). Sickle cell disease: renal manifestations and mechanisms. Nature Review Nephrology, 11: 161-71.

Neafsey P, Ginsberg G, Hattis D, Sonawane B. (2009). Genetic polymorphism in cytochrome P450 2D6 (CYP2D6): Population distribution of CYP2D6 activity. Journal Toxicology and Environmental Health - Part B: Critical Reviews, 12(5-6):334-361.

Nevitt SJ, Jones AP, Howard J.(2017). Hydroxyurea (hydroxycarbamide) for sickle cell disease. Cochrane Database Systematic Review, 4: CD002202.

Niihara Y, Miller ST, Kanter J, Lanzkron S, Smith WR, Hsu LL, Gordeuk VR, Viswanathan K, Sarnaik S, Osunkwo I, Guillaume E, Sadanandan S, Sieger L, Lasky JL, Panosyan EH, Blake OA, New TN, Bellevue R, Tran LT, Razon RL, Stark CW, Neumayr LD, Vichinsky EP; Investigators of the Phase 3 Trial of IGlutamine in Sickle Cell Disease. New England Journal of Medicine, 379: 22635.

Nishank SS, Singh MPSS, and Yadav R. (2013). Clinical impact of factor $V$ Leiden, prothrombin G20210A, and MTHFR C677T mutations among sickle cell disease patients of Central India. European Journal Haematology, 91(5):462-466.

Parent $F$, Bachir D, Inamo J, Lionnet F, Driss F, Loko G, Habibi A, Bennani S, Savale L, Adnot S, Maitre B, Yaïci A, Hajij L, O'Callaghan DS, Clerson P, Girot R, Galacteros F, Simonneau G. (2011). A hemodynamic study of pulmonary hypertension in sickle cell disease. New England Journal Medicine, 365(1):44-53.

Paule I, Sassi H, Habibi A, Pham KP, Bachir D, Galactéros F, Girard P, Hulin A, Tod M. (2011). Population pharmacokinetics and pharmacodynamics of hydroxyurea in sickle cell anemia patients, a basis for optimizing the dosing regimen. Orphanet Journal Rare Diseases, 6(6):30-42.

Pert CB, Snyder SH. (1973). Opiate receptor: demonstration in nervous tissue. Science, 179(4077):1011-1014.

Piel FB, Steinberg MH, Rees DC. (2017). Sickle cell disease. New England Journal of Medicine, 376: 1561-73.

Powars DR, Elliott-Mills DD, Chan L, Niland J, Hiti AL, Opas LM, et al. (1991). Chronic renal failure in sickle cell disease: risk factors, clinical course, and mortality. Annal of Internal Medicine, 115(8):614-620. 
Serjeant DR and Serjeant BE. Sickle Cell Disease. New York, NY: Oxford University Press; 2001.

Sery $O$, Hrazdilova O, Matalova E, Sevcik P. (2005) . Pain research update from a genetic point of view. Pain Practice, 5(4):341-348.

Sheth S, Licursi M, Bhatia M. (2013). Sickle cell disease: time for a closer look at treatment options? British Journal Haematology, 162(4):455-464.

Shiba HF, El-GhamrawyMK, Shaheen IAE, Ali RAE, and Mousa SM. (2014). Glutathione S-transferasegene polymorphisms (GSTM1, GSTT1, and GSTP1) in Egyptian pediatric patients with sickle cell disease. Pediatric and Developmental Pathology, 17:265-270.

Shord SS, Cavallari LH, Gao W, Jeong HY, Deyo $\mathrm{K}$, Patel SR, et al. (2009). The pharmacokinetics of codeine and its metabolites in Blacks with sickle cell disease. European Journal Clinical Pharmacology, 65(7):651-658.

Simon EJ, Hiller JM. (1978). The opiate receptors. Annual Review of Pharmacology Toxicology, 18:371-394.

Slade GD, Diatchenko L, Bhalang K, Sigurdsson A, Fillingim RB, Max M.B, et al. (2007). Influence of psychological factors on risk of temporomandibular disorders. Journal of Dental Research, 86(11):1120-1125.

Smith WR, Penberthy LT, Bovbjerg VE, McClish DK, Roberts JD, Dahman B, et al. (2008). Daily assessment of pain in adults with sickle cell disease. Annals of Internal Medicine, 148(2):94-101.

Snyder SH. (1984). Drug and neurotransmitter receptors in the brain. Science, 224(4644):22-31.

Snyder SH. (1977). Opiate receptors in the brain. New England Journal of Medicine, 296(5):266-271.

Stamer UM, and Stuber F. (2007). Genetic factors in pain and its treatment. Current
Opinion in Anaesthesiology, 20(5): 478484.

Steinberg MH, Barton F, Castro O, Pegelow $\mathrm{CH}$, Ballas SK, Kutlar A, et al. (2003). Effect of hydroxyurea on mortality and morbidity in adult sickle cell anemia: risks and benefits up to 9 years of treatment [published correction appears in The Journal of the American Medical Association, 290(6):756.

Steinberg MH, McCarthy WF, Castro OP, Ballas SK, Armstrong FD, Smith W et al. (2010). The risks and benefits of long-term use of hydroxyurea in sickle cell anemia: A 17.5 year follow-up. American Journal of Hematology, 85:403-408.

Todd KH, Green C, Bonham VL, Haywood C, and Ivy (E2006). Sickle cell disease related pain: Crisis and conflict. Journal of Pain, 7(7):453-458.

US Centers for Disease Control and Prevention. Sickle cell disease: data and statistics. http://www .cdc.gov/ncbddd/sicklecell/data.html. Accessed on March 8, 2014.

Vichinsky E.(2017). Chronic organ failure in adult sickle cell disease. Hematology. American Society of Hematology Education Program: 435-9.

Voskaridou E, Christoulas D, Bilalis A, Plata E, Varvagiannis K, Stamatopoulos G, et al. (2010).The effect of prolonged administration of hydroxyurea on morbidity and mortality in adult patients with sickle cell syndromes: results of a 17-year, single-center trial (LaSHS). Blood, 115(12):2354-2363.

Ware RE. (2010). How I use hydroxyurea to treat young patients with sickle cell anemia. Blood, 115 (26):5300-5311.

Ware RE, de Montalembert M, Tshilolo L, Abboud MR.( 2017). Sickle cell disease. Lancet; 390: 311-23. 